\title{
Transfer Pricing and Mangerial Ownership Against Tax Avoidance in Manufacture Companies on The Indonesia Stock Exchange
}

\author{
Rizki Fitri Amalia ${ }^{1}$, Andrew Gunawan ${ }^{2}$ \\ ${ }^{1}$ Accounting Study Program, [Polytechnic of Palcomtech] \\ ${ }^{2}$ Accounting Study Program, [Catholic University Of Musi Charitas]
}

\begin{abstract}
This study aims to analyze the influence of transfer pricing and managerial ownership of tax avoidance activity by focusing on the manufacturing companies listed in Indonesia Stock Exchange with research period in 2016-2019. The existing tax gap has become a matter of encouraging companies that have a special relationship to practice transfer pricing so that taxes paid domestically are lower than they should be paid. The data used in this research are secondary data. The population in this study are manufacturing companies listed in Indonesia Stock Exchange. The sampling selection method used was purposive sampling and obtained 126 companies with total of 380 samples. The analytical tool used in this study was the linear regression analysis. The results of this research showed that transfer pricing and managerial ownership have no effect on tax avoidance.
\end{abstract}

Keywords: Transfer Pricing, Managerial Ownership, Tax Avoidance

\section{Introduction}

One of the efforts made by the company is to minimize taxes within the limits that do not violate regulations because the tax is one of the factors of profit reduction. The amount of tax depends on the amount of income. The greater the income, the greater the tax [1]. Many efforts are performed by companies to reduce taxes, one of which is tax avoidance. This issue of corporate tax avoidance is associated with both developed and developing nations and it is a topical issue that has gained attention in the media and literature. Tax avoidance refers to an attempt to reduce tax payments by legal means, for instance by exploiting tax-loopholes [2]. According to the Organization for Economic Co-operation Development (OECD), Tax avoidance is the legal usage of the tax regime in a single territory to one's own advantage to reduce the amount of tax that is payable by means that are within the law. OECD is at the forefront of efforts to improve international tax co-operation between governments to counter international tax avoidance.

Transfer prices are the prices at which different entities of the same corporation trade. Corporations often acquire other companies to establish market advantage in their industry or achieve it through organic growth [3]. Market advantage can be achieved through lowering the cost of raw material, acquiring, developing intellectual property and other intangible assets to strengthen the longevity of their business. Through Transfer Pricing, corporations located in high-tax jurisdictions can "transfer the prices" of income and expenses and shift their income to a low-tax jurisdiction in order to avoid or reduce taxation. This transfer is done by selling 
goods and/or services to affiliates in the low-tax jurisdictions at cheaper rates resulting in low revenues for the high-tax jurisdiction company and high revenues and profits in the low tax jurisdiction. Correspondingly, the high-tax jurisdiction company purchases goods and/or services from low-tax jurisdiction affiliates at a high price resulting in high expenses for the high-tax jurisdiction company. These transactions all result in income tax avoidance. In a report containing 89 jurisdictions, in the 2018 Mutual Agreement Procedure (MAP) Statistics, the OECD noted an increase in the number of transfer pricing disputes of $20 \%$. Transfer pricing is not only performed between companies that have special relationships but can also be performed within the scope of the company itself. Efforts to exchange information and tax data from several countries have also been carried out since 2018 to obtain taxes from Indonesian citizens abroad. However, the tax avoidance that occurred has caused the country to suffer losses. There was a positive relationship between transfer pricing and tax avoidance. Financial companies more often avoid taxes through manipulation of transfer pricing than non-financial companies [4].

Besides transfer pricing, another factor that influences tax avoidance is managerial ownership. Managerial ownership is the level of share ownership owned by management who are actively involved in decision making. Through share ownership by management, company managers are expected to be able to feel directly the results of decisions taken and feel the risks directly. Management tends to work with the interests of the company rather than personal interests. Based on the phenomenon and the results of previous studies that contradict, the researchers conducted a study on tax avoidance with the title "The Influence of Transfer Pricing and Managerial Ownership on Tax Avoidance" with a sample of manufacturing companies listed on the Indonesia Stock Exchange for the 2015-2019 period [5].

Basically there are differences in interests between company owners and managers. As a result there is a conflict of interest thatcauses financial information to be conveyed asymmetrically [6]. With this information asymmetry and differences in interests, company management will tend to take actions aimed at obtaining the desired benefits by cheating, both within the company itself and at companies that have a special relationship or transfer pricing. This is performed by company management to minimize the amount of tax paid by conducting transactions at unreasonable prices. Companies that earn large profits show financial stability which has an impact on improving the performance and value of the company. So the owner orders the manager to increase the value of the company through increasing profits. One of them is with increasing load. Expenses are expenses that have an impact on the net income obtained by the company. The greater the burden on the company, the lower the net profit.

\section{Methodology}

\subsection{Hyphothesis}

\subsubsection{The Influence of Transfer Pricing on Tax Avoidance}

Transfer pricing is an economic and legal tool used by business entities for their tax burden optimization.In essence, transfer pricing means intra-company pricing of goods transferred between the enterprise subdivisions located in different countries [7]. Management of the company seeks to increase corporate profits by doing tax avoidance that does not violate applicable tax laws or tax avoidance with accounting methods, such as by moving profits to a country with lower tax rates so that the amount of tax paid becomes lower [4]. To maximize global profits and tax minimization, multinational companies have used several tax avoidance 
mechanisms as a way to shift taxable income from high tax jurisdictions to low tax jurisdictions to reduce corporate tax obligations. These mechanisms include transfer pricing, capitalization, tax haven utilization, debt financing structures, contracts, asset location strategies, and overhead costs [8].

In addition to avoiding taxes, transfer pricing is carried out to streamline the operational activities of the company. Company management can purchase materials from branch companies or companies that have a special relationship with low prices so that the total production costs of the company become lower and more efficient. So, the first hypothesis of this study is:

H1: Transfer pricing has an influence on tax avoidance

\subsection{The Influence of Managerial Ownership on Tax Avoidance}

According to agency theory, company management and shareholders have different interests. Management of the company only wants high profits by doing tax avoidance without thinking about the reputation of the company, while shareholders do not want their companies to be at risk with the management of companies that do tax avoidance. This difference in interests can cause agency problems and make the company spend agency costs to overcome. With managerial ownership, it is expected to adjust the differences between the interests of company management and shareholders.

Managerial ownership is ownership by the management of the company. Managerial ownership is also an effort that can be taken to reduce the conflict between principal and agent. Managerial ownership is the shareholder who is a party to internal company actively participates in the company's operations [9]. With managerial ownership in the company, the management of the company will also play a role as a shareholder so that the management of the company will directly feel the results and risks of the decisions taken. Thus, management will avoid negative tax practices including tax avoidance even though it does not violate tax regulations so that shareholders view the performance of the company well and are interested in investing in the company. So, the second hypothesis of this study is : H2: Managerial Ownership has negative influence on Tax Avoidance.

\subsection{Framework}

The study model is illustrated in the following figure:

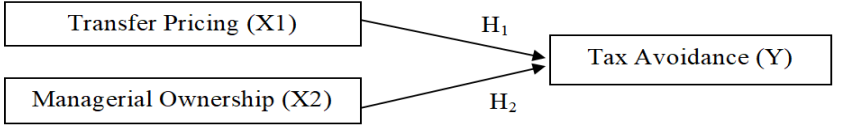

\subsection{Population and Sample}

Fig.1. Study Model

The population of this study was manufacturing companies listed on the Indonesia Stock Exchange. This study used purposive sampling. Company criteria as samples are as follows:

a) Manufacturing companies did not experience losses in 2016-2019. This is because if the company suffers a loss, the amount of tax payable from the company is zero so the company will not do tax avoidance.

b) Manufacturing companies that were not delisted in 2016-2019. This is because if the company is delisted, then there is a possibility that the data of the company is invalid because the company does not have any responsibility for the existing data. 


\subsection{Data Analysis Techniques}

This study used a multiple linear regression analysis techniques which is an analysis to determine the influence of independent variables on one dependent variable. The multiple linear regression analysis model is used to explain the relationship and influence of independent variables on the dependent variable [10]. The equation of multiple linear regression is as follows:

$$
\mathrm{Y}=\mathrm{a}+\mathrm{b}_{1} \mathrm{X}_{1}+\mathrm{b}_{2} \mathrm{X}_{2}+\mathrm{e}
$$

\section{Description:}

$$
\begin{array}{ll}
\mathrm{Y} & =\mathrm{ETR} \\
\mathrm{a} & =\text { Constant } \\
\mathrm{b}_{1} & =\mathrm{X}_{1} \text { Regression Coefficient } \\
\mathrm{b}_{2} & =\mathrm{X}_{2} \text { Regression Coefficient } \\
\mathrm{X}_{1} & =\text { Transfer Pricing } \\
\mathrm{X}_{2} & =\text { Managerial Ownership } \\
\mathrm{e} & =\text { Standard Error }
\end{array}
$$

\section{Result and Discussion}

\subsection{Hypothesis Testing}

\subsubsection{Multiple Linear Regression Analysis Test}

Table 1. Results of Multiple Linear Regression Analysis Test

\begin{tabular}{cccc}
\hline Model & B & Sig. & Conclusion \\
\hline$($ Constant $)$ & 0.488 & 0.370 & \\
\hline HT & -0.275 & 0.447 & H1 is rejected \\
\hline KM & -0.163 & 0.590 & H2 is rejected \\
\hline \multicolumn{4}{l}{ Source: Processed secondary data, 2020 }
\end{tabular}

Based on the test results in Table 1 above, the multiple linear regression analysis equation obtained is as follows:

$$
\mathrm{ETR}=0.488-0.275 H T-0.163 \mathrm{KM}+e
$$

From the regression equation above, it can be explained as follows:

a) The constant was 0.488 which means that without transfer pricing and managerial ownership, the effective tax rate will increase by 0.488 .

b) The transfer pricing coefficient was -0.275 which means if the value of managerial ownership is fixed, a unit increase of transfer pricing will cause a decrease in the effective tax rate of $-0,275$.

c) Managerial ownership coefficient was -0.163 which means if the value of transfer pricing is fixed, a unit increase of managerial ownership will cause a decrease in the effective tax rate of -0.163 . 


\subsubsection{Coefficient of Determination Test (Adjusted $\boldsymbol{R}^{2}$ )}

Table 2. Coefficient of Determination

\begin{tabular}{cc}
\hline Model & Adjusted $R$ Square \\
\hline $\mathbf{1}$ & -0.003 \\
\hline Source: Processed secondary data, 2020.
\end{tabular}

Based on Table 2, the Adjusted R Square value was -0.003 or $-0.3 \%$, which means the variables used namely transfer pricing and managerial ownership did not explain the relationship with the tax avoidance variable. Meanwhile, the remaining $100 \%$ was influenced by other variables outside the regression model.

\subsubsection{F Statistics Test}

Table 3. Results of F-Statistics test

\begin{tabular}{cc}
\hline Description & Sig. \\
\hline Regression & 0.703 \\
\hline Source: Processed secondary data, 2020.
\end{tabular}

Based on Table 4.3, the significance value of 0.703 is greater than 0.05 , which means the regression equation was not reliable or the model used was not feasible.

\subsubsection{T-test}

Based on the $t$ test performed in Table 4.1, it can be seen that :

a) The variable transfer pricing had a significance value $>0.05(0.447>0.05)$ so $\mathrm{H} 1$ is rejected.

b) Managerial ownership variable has a significance value $>0.05(0.590>0.05)$ so $\mathrm{H} 2$ is rejected.

\subsection{Discussion}

\subsubsection{Transfer pricing had no influence on tax avoidance}

Based on the results of multiple regression analysis tests, the transfer pricing variable had no influence on tax avoidance. This shows that manufacturing companies listed on the Indonesia Stock Exchange (IDX) tend not to do tax avoidance where most companies listed on IDX have smaller amounts of receivables from related parties compared to total receivables, such as Astra International and Buyung Poetra Sembada. In 2019, Astra International only had receivables from related parties of $\mathrm{Rp} 3,633,000,000,000$ from the total receivables of Rp105,923,000,000,000.00. In 2019, Buyung Poetra Sembada did not have any receivables from related parties from the total receivables of Rp250,788,820,997.00.

This is supported by the OECD Transfer Pricing Guidelines that were issued by OECD, as a guide for tax authorities and multinational companies in resolving transfer pricing issues. Thus, companies that carry out transfer pricing based on transfer pricing guidelines will not avoid taxes. Likewise with the manufacturing companies in this study, if the company conducts transfer pricing based on these guidelines, then tax avoidance will not be affected by the transfer pricing practices of the company. This is not line with research [11]. which showed that transfer pricing had significant influence (42\%) on tax avoidance.

There is a very thin grey line between tax avoidance and tax evasion. Whether corporations practice either or both, the result is the same. Critics differ with such opinions 
and consider these actions to be intentional tax evasions or tax avoidance through loopholes in the tax codes. Clearly the erosion of corporate tax revenues response to the high tax rates. Transfer pricing has been, and continues to be, the vehicle through which corporations are shifting their income to low-tax jurisdictions and in some cases to no-tax regions. As business evolves, more and more complex business transactions are created, and the lack of current legislation to prevent these transactions, creates an opportunity for excessively aggressive tax avoidance [3].

\subsubsection{Managerial ownership had no influence on tax avoidance}

Based on the results of multiple regression analysis tests, the managerial ownership had no influence on tax avoidance. This is in line with a study by [12]. which stated that managerial ownership had no influence on tax avoidance. Based on descriptive statistics, managerial ownership mean value was $8.11 \%$ and minimum managerial ownership value was 0 . Thus, managerial ownership in the companies in the study had no influence on tax avoidance because managerial ownership value was very low which only was $8,11 \%$ so that management has not been able to perform an effective supervisory function or mechanism.

For example on Astra International. In 2019, Astra International only had a number of shares owned by management of Rp24,524,900,000,000,000.00 of the total outstanding shares of Rp40,483,553,140,000,000,000.00. Even in some companies, managerial ownership value was 0, such as Akasha Wira International in 2016-2018 and KMI Wire and Cable in 20162019. This shows that managerial ownership had no influence on tax avoidance

\section{Conclusion}

Based on the results of testing the data in the previous chapter, this study proves that the variable transfer pricing and managerial ownership had no influence on tax avoidance which means transfer pricing and managerial ownership were not able to influence corporate tax avoidance. Basically, go-public companies listed on the Indonesia Stock Exchange have followed the rules in the implementation of transfer pricing. This makes tax avoidance insignificant. In addition, managerial ownership did not influence tax avoidance. This is because there are still many go-public companies that do not have managerial ownership in the company so that these become important notes for companies if they want to minimize negative practices.

\section{Suggestion}

Some suggestions that can be given for further studies are as follows: Further studies can add the sample by taking other sectors so that they can find out the differences in the variables that have been carried out in this study such as in the financial sector.

\section{References}

[1] Amalia, Rizki Fitri. (2019). Political Connection, Profitability, and Capital Intensity Against Tax Avoidance in Coal Companies on the Indonesia Stock Exchange. Atlantis press. Advances 
in Social Science, Education and Humanities Research Volume 431. ISBN 978-94-6252-953-3. ISSN.3rd Forum in Research, Science, and Technology (FIRST 2019).

[2] Aronmwan, Edosa. (2019). Corporate Tax Avoidance : Review of Measures and Prospects. International Journal of Accounting \& Finance (IJAF). Volume 8, Number 2, September.

[3] Barker, Asare and Brickman. (2017). Transfer Pricing As A Vehicle In Corporate Tax Avoidance. The Journal of Applied Business Research. Volume 33, Number 1. January/February.

[4] Amidu, Coffie, and Acquah. (2019). Transfer pricing, earningsmanagement and tax avoidance of firms in Ghana. Journal of Financial Crime Volume 26, Number 1, 2019. pp. 235-259.

[5] Ratnawati, V., Azhari, S., Freddy, D., \& Wahyuni, N. (2018). The Impact of Institutional Ownership and a Firm's Size on F irm Value : Tax Avoidance as a Moderating Variable. Journal of Finance and Banking Review. Volume 3, Number 1. Page 1-8.

[6] Putra, Syah and Simatupang. (2019). Institutional Ownership and Tax Avoidance: A Review Agency Theory. AISTSSE 2018, October 18-19, Medan, Indonesia. DOI 10.4108/eai.18-102018.2287316.

[7] Melnychenko, Pugachevska and Kasianok. (2017). Tax Control Of Transfer Pricing. Investment Management and Financial Innovations. Volume 14, Issue 4.

[8] Rossing, C. and Rohde, C. (2014). Transfer pricing: aligning the research agenda to organizational reality". Journal of Accounting and Organizational Change. Vol. 10 No. 3, pp. 266-287. https://doi.org/10.1108/JAOC-03-2012-0017

[9] Multazam and Rahmawaty. (2018). The Influence of Leverage, Executive Incentives, Managerial Ownership on Tax Aggressiveness (Study in Manufacturing Companies Listed on IDX Year 2012 - 2014. Jurnal Ilmiah Mahasiswa Ekonomi Akuntansi (JIMEKA) Volume 3, Number 3. Page 494-504.

[10] Ghozali, Imam. (2018). Aplikasi Analisis Multivariate dengan Program IBM SPSS 25. Semarang: Badan Penerbit Universitas Diponegoro.

[11] Indriaswari and Nita. (2017). The influence of tax, tunneling incentive, and bonus mechanisms on transfer pricing decision in manufacturing companies. The Indonesian Accounting Review Volume 7, Number 1. January - June. Pages 69-78.

[12] Yulistia, Minovia and Fauziati. (2020). Ownership Structure, Political Connection and Tax Avoidance. International Journal of Innovation, Creativity and Change. www.ijicc.net. Volume 11, Issue 12. 